\title{
Epitome of Research on the History of Science and Technology in China: A Review of the Book Series History of Science and Technology in Pre-Modern China in Comparison with Needham's Science and Civilisation in China ${ }^{1}$
}

\section{Dai Wusan 戴吾三2}

(Graduate School at Shenzhen, Tsinghua University, Shenzhen 518055, China)

Review of Lu, Jiaxi 卢嘉锡, ed. 1996. Zhongguo kexue jishu shi 中国科学技术史 (History of science and technology in pre-modern China). Beijing: Science Press.

\begin{abstract}
The early twenty-first century witnessed the publication of the book series Zhongguo kexue jishu shi 中国科学技术史 (History of science and technology in pre-modern China), which was initiated and organized by the Institute for the History of Natural Sciences, Chinese Academy of Sciences, and compiled by a multitude of Chinese scholars. In comparison with Science and Civilisation in China by Dr. Joseph Needham, Zhongguo kexue jishu shi is superior in the layout characteristics, literature collection, research and explication, field investigation, and simulation experiments.
\end{abstract}

Keywords: history of science and technology in China, the Institute for the History of Natural Sciences, Joseph Needham

摘 要: 21 世纪初, 由中国科学院自然科学史研究所发起和组织、众多中国学者参与编 撰的 “中国科学技术史” 从书问世。该丛书与 J. Needham (李约瑟) 博士编撰的 Science and Civilisation in China（中国科学技术史）相比, 在体系安排、文献搜集、研读阐释、 实地调查研究、模拟实验等多方面都具有特色。

关键词: 中国科学技术史, 自然科学史研究所, 李约瑟

1 This book review has been translated from Chinese into English by Lü Xin 吕昕 and copyedited by John Moffett.

2 Dai Wusan (1953-) holds a doctorate in the history of science, and is professor at the Tsinghua University Graduate School at Shenzhen, and resident research fellow at the Institute for Advanced Studies in Social Sciences, Southern University of Science and Technology. Research interests: Education and research in the history of science and technology, and science and culture. E-mail: daiws@sz.tsinghua.edu.cn 
$\mathrm{B}$ y the year 2011 all the volumes of the book series Zhongguo kexue jishu shi 中国科 学技术史 (History of science and technology in pre-modern China) had appeared in print (Figure 1). Warmly welcomed by the academic community, this grand undertaking had been initiated and organized by the Institute for the History of Natural Sciences (IHNS), Chinese Academy of Sciences (CAS), and compiled by a large number of Chinese scholars. It constitutes one of the two different, monumental research works on the history of science and technology in China, other being Science and Civilisation in China (SCC) accomplished through the lifelong endeavors of Dr. Joseph Needham (1900-1995, UK) and his co-authors.
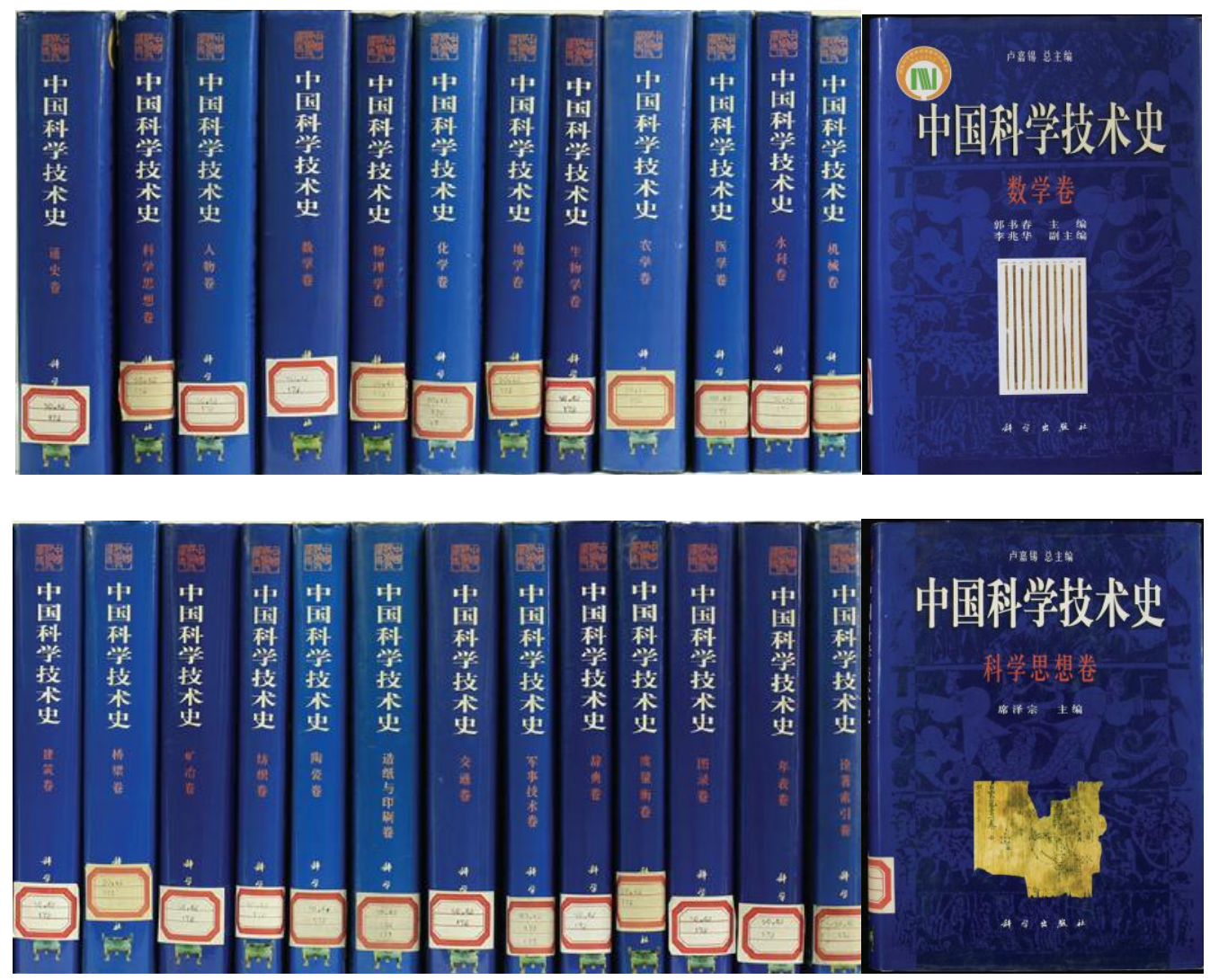

Figure 1: Zhongguo kexue jishu shi 中国科学技术史 (History of science and technology in pre-modern China).

Generations of Chinese scholars showed their commitment to the Zhongguo kexue jishu shi series, which underwent a tortuous process from conception to publication. It distills research findings from hundreds of Chinese researchers, and draws on the essence of hundreds of treatises and tens of thousands of articles. Today, some authors have passed away, so recalling their trailblazing contributions commemorates 
the pioneers of research on the history of science and technology in China.

\section{Over five decades from conception to publication}

The academic foundations for the compilation of the series date back to the research done in the 1920s to the 1930s by scholars, many of whom were scientists, into the history of science and technology in China. After the founding of the People's Republic of China in 1949, the Chinese Academy of Sciences (CAS) set about planning the institutionalization of such research, defining the principal mission as the collation of China's rich scientific heritage. Against this backdrop, in 1954, the Research Committee for the History of Natural Sciences in China was founded, as well as the Research Group for the History of Natural Sciences affiliated to the Institute of History, CAS. In January 1957, separating itself from the Institute of History, the research group became the Research Department on the History of Natural Sciences in China affiliated to CAS. Shortly after that, the department proposed the idea of composing treatises on the history of science and technology in China. However, continuous political movements thereafter disrupted the overall plan. Despite that, from the 1950s to the first half of the 1960s, the indefatigable efforts of many scholars yielded significant research results. In 1958, Kexueshi jikan 科學史集刊 (Collected articles in the history of science) was initiated by the research department, containing numerous valuable articles. This period also saw the publication of several monographs, such as Zhongguo shuxueshi 中国数学史 (A history of mathematics in China) edited by Qian Baocong 钱宝琮 in 1964, and Zhongguo jixie gongcheng famingshi diyi bian 中国机械工程发明史 - 第一编 (A history of mechanical engineering inventions, vol. 1) by Liu Xianzhou 刘仙洲 in 1962. The foundations for the series were consolidated by these works and by many other scholars contributing parts of the manuscripts or collating a wealth of research materials.

In 1975, the Research Department on the History of Natural Sciences was upgraded to the Institute for the History of Natural Sciences, bringing the planning of the book series back on to the agenda. Unexpectedly, another political disturbance soon rendered this effort fruitless. It was not until late 1978 that the reform and opening-up policy in China unfettered academic research. In the years that followed, a wide variety of works came off the press, including Zhongguo kexue jishu shigao 中国科 学技术史稿 (An introduction to the history of Chinese science and technology), Zhongguo tianwenxue shi 中国天文学史 (History of astronomy in China), Zhongguo gudai dilixue shi 中国古代地理学史 (History of geography in pre-modern China), Zhongguo gudai shengwuxue shi 中国古代生物学史 (History of biology in pre-modern China), Zhongguo gudai jianzhu jishu shi 中国古代建筑技术史 (History of the architectural technology in pre-modern China), Zhongguo guqiao jishu shi 中国古桥技 
术史 (History of bridge technology in pre-modern China), Zhongguo fangzhi kexue jishu shi: gudai bufen 中国纺织科学技术史: 古代部分 (History of textile technology in China: The pre-modern period) etc. Nonetheless, in the absence of consistent organization and coordination, the compilation plan for the series foundered once again. After some further vicissitudes, the IHNS officially brought forward the compilation plan a second time in 1987. Eventually in 1991, extensive and multi-party consultation and thorough preparation led to it being included as one of the key research projects of CAS's Eighth Five-Year plan, and it was formally launched. Lu Jiaxi 卢嘉锡, former president of CAS, undertook the role of editor-in-chief for the series (albeit in an honorary sense), and was concerned with this academic program throughout its duration.

The preparation and writing process of Zhongguo kexue jishu shi manifest the characteristics of the institutionalization of research in the history of science and technology in China. The IHNS, the initiator and organizer, set up a special academic advisory group, and recruited over thirty senior scholars, many academicians of CAS. Meanwhile, an editorial board was established. More than forty historians of science and technology served as chief editors or associate editors for separate volumes, including Bo Shuren 薄树人, Chen Meidong 陈美东, Dai Nianzu 戴念祖, Du Shiran 杜石然, Guo Shuchun 郭书春, Hua Jueming 华觉明, Zhao Kuanghua 赵匡华, Pan Jixing 潘吉星, and Xi Zezong 席泽宗. Half of them were full-time researchers from the IHNS with science and engineering backgrounds, their own research specialties, and years of history training. The other half were senior scholars from other institutes and universities who had made pioneering contributions to the discipline. These included Academician Ke Jun 柯俊 from University of Science and Technology Beijing, chief editor of the Kuangye juan 矿冶卷 (Mining and metallurgy) volume, Academician $\mathrm{Fu}$ Xinian 傅喜年 from China Building Technology Development Center, chief editor of the Jianzhu juan 建筑卷 (Architecture) volume, and Prof. Zhou Kuiyi 周鬼一 from China Institute of Water Resources and Hydropower Research, chief editor of the Shuili juan 水利卷 (Water conservancy) volume.

By 1997, the majority of the volumes of Zhongguo kexue jishu shi had been finished. In August 2008, experts organized by the Bureau of Basic Sciences, CAS checked up on the project prior to acceptance. Finally, in March 2011, the Cidian juan 辞典卷 (Dictionary) volume was published, marking the completion of all twenty-six disciplinary and comprehensive history and reference volumes. Thus, the series took over five decades from conception to publication.

\section{Layout and characteristics of Zhongguo kexue jishu shi}

When compared with Joseph Needham, the authors of Zhongguo kexue jishu shi were 
able to exploit their expertise in disciplinary history, take full advantage of their unhindered access to Chinese historical literature and archaeological discoveries, and rapidly absorb the latest research findings. In doing so, they strove to establish a comprehensive system covering more disciplines than had Needham, as well as arranging the volumes more reasonably. The time frame covered by the series is characterized by the periodization of Chinese history, concluding at the late nineteenth century.

Volumes of the book series vary from 600,000 to 1,400,000 characters, and fall into three categories:

General history (3 vols.): Tongshi juan 通史卷 (General history), Kexue sixiang juan 科学思想卷 (Scientific thought), and Renwu juan 人物卷 (Biography).

Disciplinary history (19 vols.): Shuxue juan 数学卷 (Mathematics), Wulixue juan 物理学卷 (Physics), Huaxue juan 化学卷 (Chemistry), Tianwenxue juan 天文学卷 (Astronomy), Dixue juan 地学卷 (Geosciences), Shengwuxue juan 生物学卷 (Biology), Nongxue juan 农学卷 (Agriculture), Yixue juan 医学卷 (Medicine), Shuili juan 水利卷 (Water conservancy), Jixie juan 机械卷 (Machinery), Jianzhu juan 建筑卷 (Architecture), Qiaoliang juan 桥梁卷 (Bridges), Kuangye juan 矿冶卷 (Mining and metallurgy), Fangzhi juan 纺织卷 (Textiles), Taoci juan 陶瓷卷 (Ceramics), Zaozhi yu yinshua juan 造纸与印刷卷 (Papermaking and printing), Jiaotong juan 交通卷 (Transportation), Junshi jishu juan 军事技术卷 (Military technology), and Duliangheng juan 度量衡卷 (Weights and measures).

Reference books (4 vols.): Cidian juan 辞典卷 (Dictionary), Nianbiao juan 年表卷 (Chronological table), Tulu juan 图录卷 (Album), and Lunzhu suoyin juan 论著索引卷 (Bibliographies and Indexes).

In Volume 1 of SCC published by Cambridge University Press in 1954 (pp. xvii-xxxviii), Needham outlined his plan to publish a work containing fifty sections or chapters in seven volumes. Each chapter would survey a particular subject or discipline. Thus, the early volumes contain several sections grouped into a single volume. However, as he and his co-workers did more and more research, sections lengthened and "volumes" split into several parts, with some sections eventually becoming an entire volume (or volumes) on their own. In addition, as the work grew, by the 1970s Needham and his close team realized that they would never be able to write it all, so scholars around the world were invited to write whole sections by themselves. Finally, a few sections were never completed, with the result that to date twenty-five individual books have been published, with three more still in preparation.

Thus, when comparing the two works, one can see that where some single volumes of SCC might include several subjects, Zhongguo kexue jishu shi encompasses 
not only comprehensive histories and reference books, but also only whole volumes dedicated to the history of a particular discipline.

This typical difference in layout can be illustrated by several examples. Volume 3: Mathematics and the Sciences of the Heavens and the Earth of SCC, published in 1959, includes sections on three disciplines: "Mathematics" (1 chap.), "The Sciences of the Heavens" (2 chaps.), and "The Sciences of the Earth" (4 chaps.), ${ }^{3}$ while Zhongguo kexue jishu shi has separate volumes for Mathematics, Astronomy, and Geosciences. Volume 4: Physics and Physical Technology of SCC consists of three parts, Part I: Physics, Part II: Mechanical Engineering, and Part III: Civil Engineering and Nautics. In Part I, the section "(c) Mass, mensuration, statics and hydrostatics" has only a sub-section entitled "China and the metric system." Zhongguo kexue jishu shi, on the other hand, has an entire, and far more informative, volume on Weights and measures. Chapter "28 Civil Engineering" in Part III, Volume 4 of SCC includes sections "(b) Roads," "(e) Bridges," and "(f) Hydraulic engineering," whereas Zhongguo kexue jishu shi deals with the topics in much greater length in the Transportation, Bridges, and Water conservancy volumes.

Traditional Chinese medicine is a self-contained system with a rich literature that has produced a myriad physicians. Needham's early research framework planned to discuss medicine in sections of Volume 6: Biology, Agriculture and Medicine, including chapters " 43 The Institutes of Medicine: Anatomy, Physiology, and Embryology," "44 Medicine," and "45 Pharmaceutics." However, due to commitments to other sections Needham and his co-author Lu Gwei-djen were unable to complete these sections, and by the 1980s the volume of new research on medicine in China had overwhelmed them. As a result, a special monograph outside the series was published on acupuncture. In addition, Professor Nathan Sivin, an American historian of science, was asked to bring together five articles on Chinese medicine previously published by Needham and $\mathrm{Lu},{ }^{4}$ writing an introduction setting them in their context and surveying the latest research by scholars from around the world. The result was Volume 6, Part IV: Medicine, a slim volume very different to the others in the series, which can hardly be described as systematic.

In the case of Zhongguo kexue jishu shi, there is one single volume entitled Medicine. The first five segments of this volume follow a chronological order in eighteen chapters, spanning the Pre-Qin period, the Qin, Han, Western and Eastern Jin, and Northern and Southern dynasties through to the Sui, Tang, Song, Jin, and Yuan dynasties, and finally the Ming and Qing dynasties. The sixth segment centers on

3 Contents of SCC (vol. 3): "19 Mathematics," "20 Astronomy," "21 Meteorology," "22 Geography and Cartography," "23 Geology," "24 Seismology," and "25 Mineralogy."

4 These five are "Medicine in Chinese culture," "Hygiene and preventive medicine," "Qualifying examinations," "The origins of immunology," and "Forensic medicine." 
medical exchanges between China and other countries in seven chapters, elaborating on interchanges between China and Korea, Japan, Southeast Asia, India, Arabia, and the West, as well as the transmission of traditional Chinese medicine to the West.

These comparisons points to the fact that although parts and volumes bear similar titles, Zhongguo kexue jishu shi is very different from its counterpart in layout.

Other parts and volumes can also reflect the layout difference between the two works. Yet differences in layout alone cannot indicate the merits of Zhongguo kexue jishu shi, because ground-breaking research should be the most important aspect.

\section{Findings and reception of Zhongguo kexue jishu shi}

After the 1920s and 1930s, especially after 1949 until the late 1980s, research in the history of science and technology in China flourished. As Dr. Joseph Needham stated in 1988: "During the past thirty years there has been a veritable explosion of new knowledge and understanding about the part played by China and Chinese culture in the ancient and medieval history of science, technology and medicine" (Needham 1988). As a result, Chinese scholars launched the Zhongguo kexue jishu shi project from a well-developed position, and were confident of showcasing a wealth of new research.

For instance, the Mathematics volume comprehensively encapsulates works of several generations of historians of Chinese mathematics, systematically analyzing the subject's principal documents, mathematicians, significant achievements, and modes of thinking. It includes extensive discussion on certain controversial topics, such as the features of Chinese mathematical texts, and whether theories and proofs existed in ancient Chinese mathematics. The authors of this volume note that such treatises as Jiuzhang suanshu 九章算術 (The nine chapters on mathematical procedures) abound with correct, universal, and abstract methods concerning certain kinds of mathematical problems, which are themselves mathematical theories. Jiuzhang suanshu zhu 九章算術注 (Commentary on The nine chapters on mathematical procedures) by Liu Hui 劉徽 (died ca. 295 CE) provides detailed proofs for some formulas and algorithms in Jiuzhang suanshu, and demonstrates rigorous logic (Guo 2010).

Let us also take a look at the Physics volume. Historians in China have formed their own views about ancient Chinese physics. Dai Nianzu 戴念祖, editor-in-chief of this volume, deemed that "the volume [by Needham] on Physics and Physical Technology appeared to be insufficient, resulting from the absence of related research when Needham was writing it. When we embarked on the Physics volume, we were able to systematically elucidate accomplishments of pre-modern Chinese physics regarding 
power, sound, light, electricity, magnetism, and heat" (Wang 2008). ${ }^{5}$

The Medicine volume benefitted from the extensive research output on the ample historical materials regarding medicine in pre-modern China. Its survey of the origin and development of medicine in China is well-informed, giving an overall assessment of medical schools and classic works from across the ages, and documents the activities and academic thought of renowned physicians. Furthermore, placing equal weight on the history of science and technology and the history of social culture, it concentrates on the connection between the social background of philosophy, religion, politics, etc. and thought and therapeutic techniques in traditional Chinese medicine.

It is justifiable to say that subjects which are confined to only a section in SCC due to the lack of available literature and sparse research base are distributed in various chapters of Zhongguo kexue jishu shi with adequate materials and well-grounded explanations.

In another case, novel findings were made by Chinese scholars in chemistry in pre-modern China, a subject in which Needham was well-versed. From 1963, Needham and Lu Gwei-Djen published a string of articles, in one of which they pointed out that qiu shi 秋石 (autumn mineral, urinary solids) mentioned in Su Shen liangfang 蘇沈良方 (Excellent formulas of Su and Shen) (by Shen Kuo 沈括 (1031-1095) in the Song dynasty) could be relatively pure steroid sex hormones, nothing less than a sensation in the international community of the history of science at the time. Liu Guangding 刘广定, a scholar from Taiwan Province, subsequently published three papers questioning Needham and Lu's proposition from the standpoint of modern organic chemistry. This stimulated Zhang Binglun 张秉伦 and Sun Yilin 孙毅霖, scholars from Chinese mainland, to carry out meticulous simulation experiments. The results supported Liu's viewpoint, and proved that the qiu shi acquired by Shen Kuo was merely a mixture of inorganic salts based on sodium chloride without sex hormone content (Zhao and Zhou 1998).

Zhongguo kexue jishu shi has been well received in China since its publication. Several volumes have been granted the Guo Moruo Chinese History Award, to date the highest history award on the Chinese mainland (established in 1998, held every three to five years). The 2007 award conferred second place on the Scientific thought volume, edited by Academician Xi Zezong, and third place on the Water conservancy volume, written by Zhou Kuiyi. The ensuing 2012 award awarded first place to the Mathematics volume, edited by Guo Shuchun. Such awards speak volumes for the acceptance of this series in history circles in China.

Zhongguo kexue jishu shi also has had widespread influence overseas. For instance,

5 “李约瑟写他的 “物理学卷” 时, 有关的研究还非常少, 所以该书内容显得非常单薄; 而到我 们动笔时, 已经可以比较系统地论述中国古代物理学在力、声、光、电、磁、热等诸方面所取得 的成就了。” 
a Korean translation of the Medicine volume was published in South Korea, while LES NEUF CHAPITRES: Le Classique mathématique de la Chine ancienne et ses commentaires, closely connected with the Mathematics volume, was published in Paris in 2004.

Also warranting our attention is the 2018 list (fifth batch) of Heritage Irrigation Structures (HIS) announced at the 69th International Executive Council Meeting of the International Commission on Irrigation and Drainage held in Saskatoon, Canada in August 2018. Four candidates from China were on the list, including the Dujiangyan irrigation system, the Lingqu Canal, the Jiang-Xi Dam, and the Changqu Canal. Amongst the first four batches, thirteen from China were included, such as the Dongfeng Weir in Jiajiang, Sichuan, the Tongji Canal in Lishui, Zhejiang, and the Mulanpo irrigation system in Putian, Fujian. This inclusion of seventeen locations in the HIS lists symbolizes China's rich endowment of hydraulic heritage structures, outstanding irrigation efficiency, and extensive distribution. The Water Conservancy volume of Zhongguo kexue jishu shi details all these irrigation systems. Arguably, the success of being listed as an HIS is underpinned by well-founded academic research.

\section{The core questions and deficiencies of Zhongguo kexue jishu shi}

The general preface of Zhongguo kexue jishu shi states that research on the history of science and technology in China "should answer the following questions: What kinds of science and technology existed in pre-modern China? What were their value, roles, and impact? How were they developed? What position do they hold in the global history of science and technology? Why is this so, and what enlightenment can we gain?" (Lu 1996). ${ }^{6}$ These are fundamental issues for studies in the history of science and technology, though they appear somewhat broad. What stands out as most noteworthy for this series is that the authors of the more than twenty volumes of Zhongguo kexue jishu shi provide comprehensive and systematic answers to the first and most fundamental of these questions, "what kinds of science and technology existed in pre-modern China?" In comparison, such questions as "What position do they hold in the global history of science and technology?" relate to the comparison of different disciplines and regions worldwide, the diffusion of knowledge, and value judgments. If such a topic is not assigned separate volumes, many readers may not be so impressed, and Zhongguo kexue jishu shi precisely lacks a specific volume centering on this issue.

In 1954, Joseph Needham trenchantly raised a series of questions in the preface to Volume 1 of SCC. A decade later, he restated them more succinctly and clearly in the

6 “要回答下列一些问题: 中国古代有过什么样的科学技术? 其价值、作用与影响如何? 又走过 怎样的发展道路? 在世界科学技术史中占有怎样的地位? 为什么会这样, 以及给我们什么样的启 示?” 
well-known article "Science and Society in East and West":

... why modern science had not developed in Chinese civilisation (or in Indian) but only in Europe? As the years went by, and as I began to find out something at last about Chinese science and society, I came to realise that there is a second question at least equally important, namely, why, between the -1 st and the +15 th centuries, Chinese civilisation was much more efficient than occidental in applying human natural knowledge to practical human needs? (Needham 1965, 174)

This is the standard version of what has become known as the "Needham Question" (also known as the "Needham Problem" or "Needham Puzzle"), and serves as the central issue for the volumes of SCC. Even though Needham didn't dedicate a specific volume to answering this question, his discussions are instructive. The "Needham Question" continues to evoke broad interest in the academic world, and related debates have expanded even beyond academic circles.

Conception of the Zhongguo kexue jishu shi series commenced in the 1950s, and was to some degree affected by the social background of the time. For example, some authors continued to use certain ideological expressions, such as "feudal society" and "feudal ideology." Driven by the needs of patriotic education at a particular time, quite a few authors intentionally focused on finding "world-leading" discoveries and inventions in pre-modern China, sometimes making exaggerated claims. Although the authors attempted to overcome preconceived notions, many signs of such attitudes still found their way into the volumes.

In comparison with Needham's SCC, Zhongguo kexue jishu shi has two evident shortcomings.

(1) Zhongguo kexue jishu shi is inadequate in macro comparative studies. As Needham often remarked, the first ancient Chinese classic he encountered when he was learning Chinese was Guanzi 管子 (Book of Master Guan). After comparing Guanzi with works of the ancient Greeks, he concluded that it was imbued with many extraordinary ideas. Comparative studies should be premised upon different texts. For example, Volume 2: History of Scientific Thought of SCC categorizes the bibliography into three kinds (about 1760 items in total): “A. Chinese Books before +1800," "B. Chinese and Japanese Books and Journal Articles since +1800 ," and "C. Books and Journal Articles in Western Languages" (circa 400, 110, and 1250, respectively) (Needham 1956, 585; Dai 1992). The authors of Zhongguo kexue jishu shi, like many scholars of their generation were clearly constrained from conducting macroscopic comparisons because of limitations imposed by a lack of access to western books, foreign language teaching and academic exchanges with colleagues abroad. As a result, there is a noticeable dearth in their use of foreign publications.

(2) Scientific and technological thought in pre-modern China is not delved into or 
explicated in sufficient depth or clarity, and there is a pronounced insufficiency in the linking ancient science and technology to social development. Zhongguo kexue jishu shi includes volumes of mixed levels, for instance those that provide plentiful archaeological materials and the results of scientific testing, but which lack sufficient historical explication and philosophical analysis. Cognizant of this problem, Hua Jueming 华觉明, one of the editors-in-chief of the Machinery volume, remarked as follows:

Human engineering activities derive from views on and thinking about technology, which should be a vital part of research on the history of mechanical engineering. . . In recent years, studies in this field have captured the attention of scholars at home and abroad, who have engaged in valuable, though only preliminary investigations. Research on external history in regard to the relationship between mechanical engineering and social development also remains a gap to be urgently bridged. (Lu and Hua 2000,423$)^{7}$

This can be read as awareness of the limitations of Chinese scholars' research on the history of science and technology in pre-modern China, as well as inspiration for subsequent researchers.

In summary, compiled by a large number of scholars, Zhongguo kexue jishu shi required a span of twenty years from official commencement to eventual completion, and deserves the reputation as a comprehensive work of studies on the history of science and technology in China. In spite of that, the series by no means exhausts pertinent research, the pre-modern parts in particular. Of course, since its publication, new findings have been made in many areas through new archaeological discoveries, new field investigations, simulation experiments and textual research. Promisingly, future versions of Zhongguo kexue jishu shi will assuredly be more inclusive and informative.

\section{Acknowledgments}

The author would like to extend his special thanks to those who shed light on pertaining fields in Zhongguo kexue jishu shi, as well as the anonymous reviewers who offered constructive feedback.

7 “人们的工程技术活动, 来自人们的技术观与技术思想。因而技术观与技术思想的研究理应成 为机械工程技术史研究的一个重要方面。……近年来, 这一领域的研究已引起国内外学者的重视 并做了一些有价值的探索, 但仍只是开始; 至于机械工程技术与社会发展相互关系的外史研究则 更接近空白, 亟待弥补。” 


\section{References}

Dai, Wusan 戴吾三. 1992. “Lun Liyuese Zhongguo kexue jishu shi de tese” 论李约瑟《中国科学 技术史》的特色 (On the characteristics of Joseph Needham's Science and Civilisation in China). Paper presented at the International Symposium on the History of Science and Technology in China (Hangzhou).

Guo, Shuchun 郭书春, ed. 2010. “Qianyan” 前言 (Preface). In Zhongguo kexue jishu shi: Shuxue juan 中国科学技术史 - 数学卷 (History of science and technology in pre-modern China: Mathematics). Beijing: Science Press.

Lu, Jiaxi 卢嘉锡. 1996. “Zongxu” 总序 (General preface). In Zhongguo kexue jishu shi. Beijing: Science Press.

Lu, Jingyan 陆敬严, and Hua Jueming 华觉明. 2000. Zhongguo kexue jishu shi: Jixie juan 中国科 学技术史 ・机械卷 (History of science and technology in pre-modern China: Machinery). Beijing: Science Press.

Needham, Joseph, with the research assistance of Wang Ling. 1956. Science and Civilisation in China: Volume 2: History of Scientific Thought. Cambridge: Cambridge University Press.

Needham, Joseph. 1965. “Science and Society in East and West." Centaurus 10 (3): 174-197.

Needham, Joseph. 1988. "Preface for the integral translation of 'Science and Civilisation in China' presided over by Lu Chia-Hsi." The Needham Research Institute, UK.

Wang, Hongbo 王洪波. 2008. “Zhongguoren ziji bianzhu de Zhongguo kexue jishu shi” 中国人自 己编著的《中国科学技术史》 (The Chinese-compiled History of science and technology in pre-modern China). Zhonghua dushubao 中华读书报 (China Reading Weekly), October 2, 4.

Zhang, Mengwen 张孟闻. 1989. Liyuese boshi jigi Zhongguo kexue jishu shi 李约瑟博士及其《中国 科学技术史》 (Dr. Joseph Needham and his Science and Civilisation in China). Shanghai: East China Normal University Press.

Zhao, Kuanghua 赵匡华, and Zhou Jiahua 周嘉华. 1998. “Xulun” 绪论 (Introduction). In Zhongguo kexue jishu shi: Huaxue juan 中国科学技术史 - 化学卷 (History of science and technology in pre-modern China: Chemistry). Beijing: Science Press. 


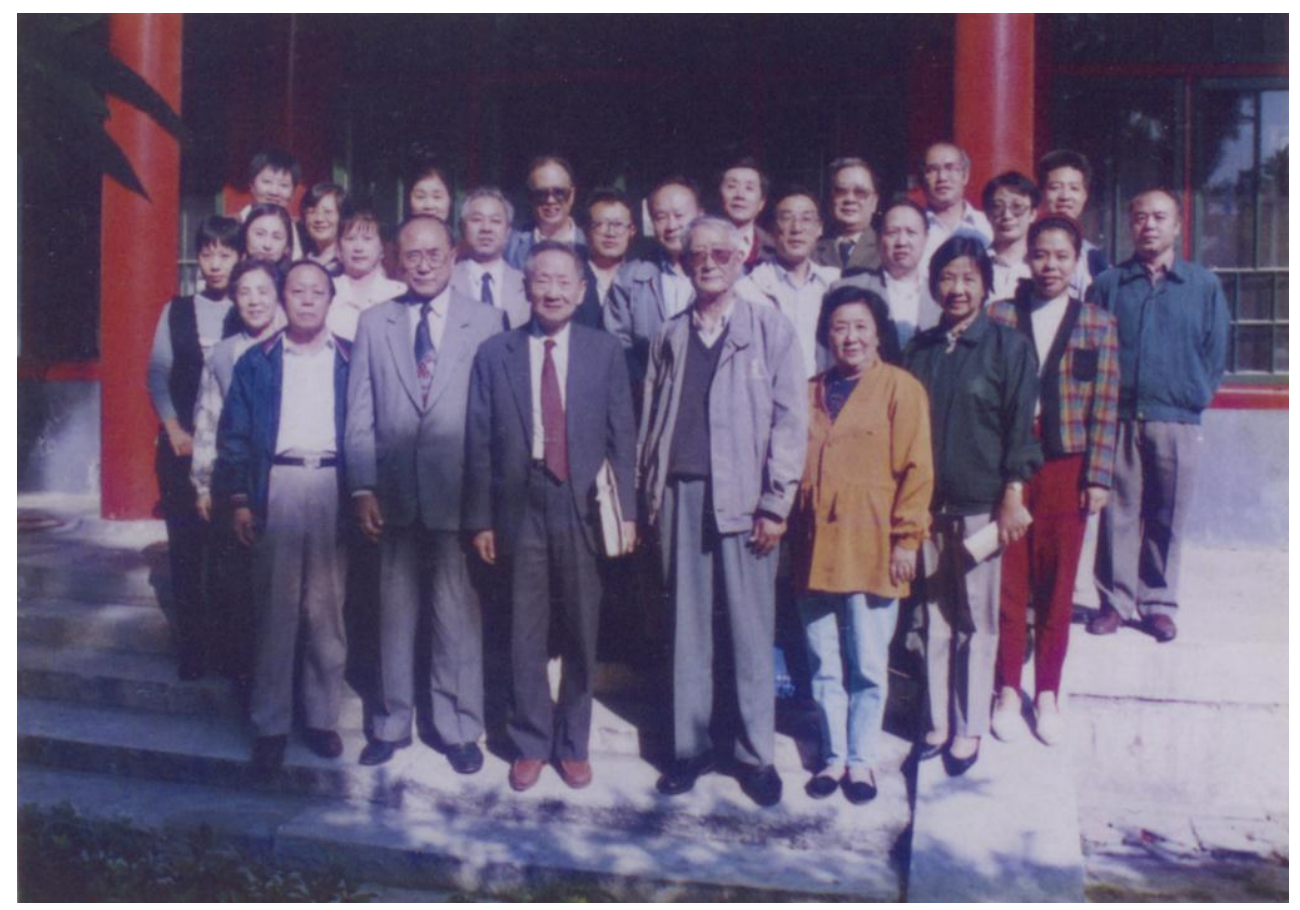

Editorial Board Meeting of Zhongguo kexue jishu shi 中国科学技术史 (History of science and technology in pre-modern China). 